
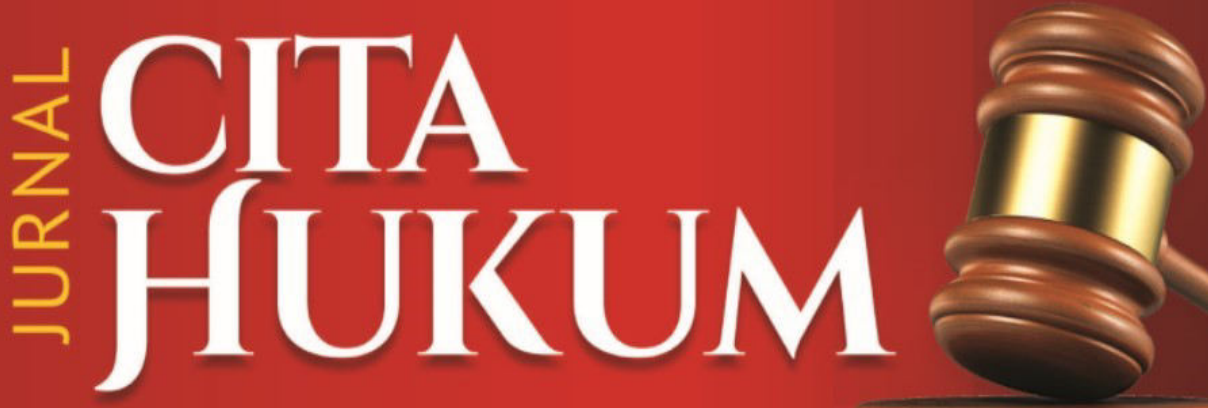

Indonesian Law Journal

- Mediation from the Penological Viewpoint

Mohammad Hossein Hajaryan, Iraj Golduzian \& Ehsan Hajarian. (Islamic Republic of Iran)

- Considering the Living Law as A Source in National Legal Development

Achmad Irwan Hamzani, Havis Aravik, Mukhidin \& Eddy Praptono. (Tegal, Indonesia)

- Legal Review of the Liability Framework for Remote Sensing by Looking at the Global Navigation Satellite System

Simin Asadzadeh Talei, Sepideh Bouzari \& Sakineh Bagheri. (Islamic Republic of Iran)

- Prevention Model of Disguised Crime in Indonesian Banking Facing the Deviation Actions of The Credit Use/Side Streaming by Debtor; Theoretical Review on Risk Management of Default Due to Side Streaming

Mas Ahmad Yani \& Muhammad Mustofa. (Jakarta, Indonesia)

- Limitation and Reduction of Human Rights in Indonesia Through Substitute Governmental Regulations

Marli Candra, Tigor Einstein \& Muhammad Ishar Helmi. (Malaysia)

- A Comparative Study of Gay and Lesbian Movement in Indonesia and America for the Struggle of Equality Recognition

Aprilina Pawestri, Supanto \& Isharyanto. (Surakarta, Indonesia)

- Legal Characters of Partnership Agreement 212 Mart

Mulhadi \& Zulkifli Sembiring. (Medan, Indonesia)

- Reformulation of the Monitoring on Political Party Fund System; A Case of Indonesian Political Party System

Muhammad Aljabar Putra, Rezky Panji Perdana Martua Hasibuan \& Indra Rahmatullah. (Jakarta, Indonesia)

- Проблемы Пробуждения Коммунизма и Халифата как Форма Чёрной Кампании на Президентских Выборах в Индонезии в 2019 Году (Issues of the Awakening of Communism and Khilafah as a Form of a Black Campaign in the Presidential Election in Indonesia in 2019)

Zahrotunnimah \& Ida Susilowati. (Ulfa, Federasi Russia)

\title{
Volume 7 Number 2 (2019)
}




\section{Jurnal}

\section{CITA HUKUM}

\section{VOLUME 7 NUMBER 2 (2019)}

JURNAL CITA HUKUM is Indonesian Law Journal published by Faculty of Sharia and Law, State Islamic University Syarif Hidayatullah Jakarta in Associate with Center for Study of Indonesian Constitution and Legislation (POSKO-LEGNAS) UIN Jakarta.

This journal specializes in Legal Studies and try to present various results of the latest and high-quality scientific research.

As an International Journal, all articles must be written in English or Russian, because they will be read online by millions of readers, both speakers of English and Russian.

JURNAL CITA HUKUM has been indexed at Web of Science (WOS) Web of Science (WOS) or Emerging Source Citation Index (ESCI)

Clarivate Analytics, DOAJ, EBSCO, DIMENSION, Microsoft Academic Search, and SINTA 3 and become a CrossRef Member since year 2015. Therefore, all articles published by JURNAL CITA HUKUM will have unique DOI number.

\section{INTERNATIONAL EDITORIAL BOARD}

Prof. Carolyn Sappideen, Scopus ID: 6506771331 School of Law Western Sydney University, Australia

Prof. Alexander Fedorovich Malyy, Scopus Id: 57194874834, Department of Constitutional Law, Kazan Federal University, Russian Federation

Prof. Razeen Sappideen, Scopus ID: 14041008300 School of Law Western Sydney University, Australia

Prof. Stanislav Shkel, Scopus Id: 56747984200, Department of Constitutional Law, Ufa State Petroleum Technological University, Russian Federation

Prof. Stefan Koos, Bundeswehr University Munich

Prof. Muhammad Munir, Scopus ID: 54414595100, Department of Law, International Islamic University Islamabad, Pakistan

Prof. Euis Nurlaelawati, Scopus ID: 56247081700, Faculty of Sharia and Law, State Islamic University (UIN) Sunan Kalijaga Yogyakarta

Prof Abdul Gani Abdullah, Universitas Islam Negeri Syarif Hidayatullah Jakarta

Prof. Salman Maggalatung, Center for the Study of Constitution and National Legislation (POSKOLEGNAS), Indonesia

Assoc. Prof. Asep Saepudin Jahar, Scopus ID: 57156653300, Department of Economic Law Universitas Islam Negeri Syarif Hidayatullah Jakarta

Assoc. Prof. Ahmad Tholabi Kharlie, Thomson Reuters Id: R-5028-2017, Department of Family Law, Faculty of Sharia and Law, Universitas Islam Negeri Syarif Hidayatullah Jakarta

\section{EDITOR IN CHIEF}

Nur Rohim Yunus, Scopus ID: 57210890976, Thomson Reuters Researcher ID: F-3477-2017, ORCID ID: 0000-0003-27821266, SSRN ID: 2645355, SINTA ID: 5975443, Department of Constitutional Law, UIN Syarif Hidayatullah Jakarta, Indonesia

\section{MANAGING EDITOR}

Muhammad Ishar Helmi, Thomson Reuters Researcher ID: F-3345-2017, ORCID ID: 0000-0001-7060-8191, SINTA ID: 6199804, Department of Criminal LaN UIN Syarif Hidayatullah Jakarta, Indonesia.

\section{EDTORS}

Indra Rahmatullah, ORCID ID: 0000-0002-6160-4225, SINTA ID: 6200500, Department of Economic Law, Faculty of Sharia and Law, UIN Syarif Hidayatullah Jakarta, Indonesia.

Fitria Fitria, ORCID ID: 0000-0001-9733-1233, Department of International Law, York Law School, University of York, UK, United Kingdom.

Mara Sutan Rambe, ORCID ID: 0000-0001-5404-6635, SINTA ID: 6200494, Department Criminal Law, Faculty of Law, UIN Syarif Hidayatullah Jakarta, Indonesia. Erwin Hikmatiar, Thomson Reuters Researcher ID: F-3235-2017, ORCID ID: 0000-0003-4103-818X, SINTA ID: 6200141, Center for The Study of Constitution and National Legislation (POSKOLEGNAS), UIN Jakarta.

Arip Purkon, ORCID ID: 0000-0002-6195-9384, Department of Law, University of Malaya, Malaysia.

\section{LANGUAGE EDITOR (ENGLISH AND RUSSIA)}

Raisa Shahrestani, Belgorodsky State University, Russia.

Firsty Izzata Bella, State Islamic University (UIN) Syarif Hidayatullah Jakarta, Indonesia.

\section{ASSISTANT TOTHE EDITORS}

Anisaul Kamilah. State Islamic University (UIN) Syarif Hidayatullah Jakarta, Indonesia. Firda Zahra, State Islamic University (UIN) Syarif Hidayatullah Jakarta, Indonesia.

\section{Redaktur Office}

Faculty of Sharia and Law UIN Syarif Hidayatullah Jakarta

Street Ir. H. Juanda 95 Ciputat Jakarta 15412

Phone. (62-21) 74711537, Faks. (62-21) 7491821

Website: www.fsh-uinjkt.net, E-mail: jurnal.citahukum@uinikt.ac.id

Link: http.//joumal.uinjkt.ac.id/index.php/citahukum 


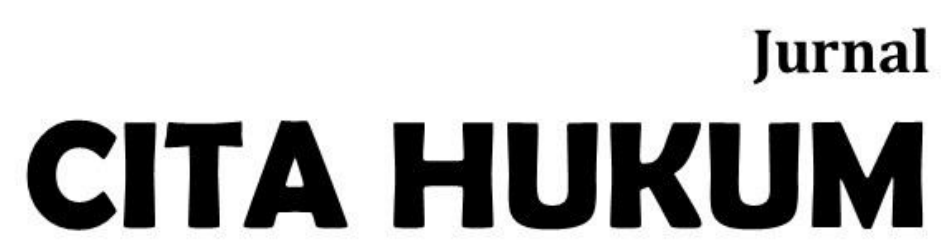

INDONESIAN LAW JOURNAL

Welcoming contributions from scientists, scholars, professionals, and researchers in the legal disciplines to be published and disseminated after going through script selection mechanisms, reviewing sustainable partners, and rigorous editing processes. 


\section{TABLE OF CONTENTS}

Mediation from the Penological Viewpoint

Mohammad Hossein Hajaryan, Iraj Golduzian, Ehsan Hajarian

Considering the Living Law as A Source in National Legal Development

Achmad Irwan Hamzani, Havis Aravik, Mukhidin, Eddy Praptono

Legal Review of the Liability Framework for Remote Sensing by Looking at the Global Navigation Satellite System

Simin Asadzadeh Talei, Sepideh Bouzari, Sakineh Bagheri 191-198

Prevention Model of Disguised Crime in Indonesian Banking Facing the Deviation Actions of The Credit Use/Side Streaming by Debtor; Theoretical Review on Risk Management of Default Due to Side Streaming

Mas Ahmad Yani, Muhammad Mustofa 199-212

Limitation and Reduction of Human Rights in Indonesia Through Substitute

Governmental Regulations

Marli Candra, Tigor Einstein, Muhammad Ishar Helmi $213-234$

A Comparative Study of Gay and Lesbian Movement in Indonesia and America for the Struggle of Equality Recognition

Aprilina Pawestri, Supanto, Isharyanto $235-252$

Legal Characters of Partnership Agreement 212 Mart

Mulhadi, Zulkifli Sembiring.$253-270$

Reformulation of the Monitoring on Political Party Fund System; A Case of Indonesian Political Party System

Muhammad Aljabar Putra, Rezky Panji Perdana Martua Hasibuan,

Indra Rahmatullah . $271-290$

Проблемы пробуждения коммунизма и халифата как форма чёрной кампании на президентских выборах в Индонезии в 2019 году

(Issues of the Awakening of Communism and Khilafah as a Form of a Black Campaign in the Presidential Election in Indonesia in 2019)

Zahrotunnimah, Ida Susilowati 291-306 
JURNAL CITA HUKUM (Indonesian Law Journal)

FSH UIN Syarif Hidayatullah Jakarta

Vol. 7 No. 2 (2019), pp.169-190, DOI: 10.15408/jch.v7i2.10951

\title{
Considering the Living Law as A Source in National Legal Development
}

\author{
Achmad Irwan Hamzani, ${ }^{1}$ Havis Aravik, ${ }^{2}$ Mukhidin, ${ }^{3}$ Eddy Praptono ${ }^{4}$ \\ ${ }^{1,3,4}$ Faculty of Law, Pancasakti University Tegal, Indonesia \\ 2STEBIS Indo Global Mandiri, Palembang, Indonesia
}

\section{$\underline{10.15408 / j \mathrm{jch} . v 7 i 2.10951}$}

\begin{abstract}
:
The construction of national law is one of the projects that has not been completed to this day in Indonesian law. Legal development should ideally pay attention to existing legal sources, especially laws that have become community culture. The results of this study show that legal development must be able to produce legal product reforms to replace the Dutch colonial legacy regulations that do not reflect the values and interests of the Indonesian people and encourage the growth of government and national development activities that originate from Pancasila and the 1945 Constitution. Incorporating the living law in the development of national law is an accommodative policy so that the national law produced is truly a product that is able to protect and protect all heterogeneous components of the Indonesian nation with their different backgrounds and legal needs
\end{abstract}

Keyword: The living law, the source of law, the development of national law, Islamic law

\section{How to cite (Turabian):}

Hamzani, Achmad; Aravik, Havis; Mukhidin; and Praptono, Eddy. "Considering the Living Law as A Source in National Legal Development" Jurnal Cita Hukum [Online], Volume 7 Number 2 (17 August 2019).

* Received: June 17, 2019, revised: July 22, 2019, accepted: July 30, 2019, Published: August 17, 2019.

${ }^{1}$ Achmad Irwan Hamzani is an Associate Professor at Faculty of Law, Pancasakti University Tegal, Indonesia.

2 Havis Aravik is a Senior Lecturer at STEBIS Indo Global Mandiri, Palembang, Indonesia.

${ }^{3}$ Mukhidin is a Lecturer at at Faculty of Law, Pancasakti University Tegal, Indonesia.

${ }^{4}$ Eddy Praptono is a Lecturer at at Faculty of Law, Pancasakti University Tegal, Indonesia.

*Corresponding Author: hamzaniachmad@gmail.com 


\title{
Mempertimbangkan Living-Law Sebagai Sumber Dalam Pengembangan Hukum Nasional
}

\begin{abstract}
Abstrak
Konstruksi hukum nasional adalah salah satu proyek yang belum selesai hingga saat ini dalam hukum Indonesia. Pengembangan hukum idealnya harus memperhatikan sumber hukum yang ada, terutama hukum yang telah menjadi budaya masyarakat. Hasil penelitian ini menunjukkan bahwa pengembangan hukum harus mampu menghasilkan reformasi produk hukum untuk menggantikan peraturan peninggalan kolonial Belanda yang tidak mencerminkan nilai-nilai dan kepentingan rakyat Indonesia dan mendorong tumbuhnya kegiatan pemerintah dan pembangunan nasional yang berasal dari Pancasila dan UUD 1945. Memasukkan hukum yang hidup dalam pengembangan hukum nasional adalah kebijakan yang akomodatif, sehingga hukum nasional yang dihasilkan benar-benar merupakan produk yang mampu melindungi semua komponen bangsa Indonesia yang heterogen dengan latar belakang dan kebutuhan hukum yang berbeda-beda.
\end{abstract}

Kata Kunci: Hukum Yang Hidup, Sumber Hukum, Pengembangan Hukum Nasional, Hukum Islam

\section{Рассмотрение действующих прав как источник развития национального права}

\begin{abstract}
Аннотация
Построение национального права является одним из проектов, который до сих пор не завершен в индонезийском законодательстве. В идеале, при развитии национального права следует обратить внимание на источники действующего права, особенно права, ставшего культурой сообщества. Результаты этого исследования показывают, что правовое развитие должно происходить в виде ресрорм правового продукта, чтобы заменить наследие голландских колониальных правил, которые не отражают ценности и интересы индонезийского народа, и стимулировать рост правительственной деятельности и национального развития, основанных на принципах Панчасилы и Конституции 1945 года. Включение действующих прав в развитие национального права является услужливой политикой, поэтому получившийся национальный закон действительно является продуктом, способным защитить все составляющие гетерогенного индонезийского народа $c$ различным происхождением $и$ юридическими потребностями.
\end{abstract}

Ключевые Слова: Действующее Право, Правовые Источники, Развитие Национального Права, Исламское Право. 


\section{Introduction}

Laws and sources of law are inseparable from one another. The existence of law is determined from the source of law and the source of the law is unlikely to have a binding effect if it is not formulated and entered into law. Law is something that is needed by society, without law in society, there will be various conflicts. Good law is a law that is able to accommodate various interests of the community and resolve conflicts that occur in the community (Milovanovic, 1994: 12), which contain various rights and obligations that lead to the realization of security and order in the community. Through the law, individuals or communities can live a decent and dignified life. It is because; law is a mechanism of social control and giving legal recognition and punishing unapproved behavior (Abel, 2017, p. 374). Thus, the law that can play a role is a law that always serves the interests to support the realization of a prosperous society (Yusuf, 2015: 1).

Law is the core of civilization and a reflection of the nation's soul (Kabalmay, 2010: 22). The law that successfully guarantees a lot of legal certainty in the community is a useful law. In a sense, if the application of legal norms provides good benefits for the community and creates welfare for other communities (Sagama, 2016: 590). For this reason, the law must be sourced and taken from norms that have been united and become part of the community, one of which is religious norms derived from religious law. This is very reasonable because law is a norm that invites people to achieve certain ideals and conditions without ignoring the world of reality (Rahardjo, 2012: 25). Development of national law, both formal and material, must come from and refer to religious law and not neglect the moral values contained in it. It is because; the end of the law lies in the community and is oriented towards the community as part of the perpetrators and implementers of religious law as its followers.

Departing from the above problems, the study of the living law as one of the sources of national law development is very interesting besides sometimes there are many legal rules that are biased and deviate from the living law norms, but it becomes very important because religion is a life belief that rooted and implemented in totality by the community which incidentally is an active law actor. Therefore, ignoring the potential and urgency of the living law in giving birth to new national law products would actually make the law far from the community and later it would not be useful and produce benefits for the community. Especially because of the chaos of the law today due to losing identity due to external influences which are increasingly difficult to contain, 
internal forces need to fight and filter it (Rahardjo, 2008: 214), one of them is by re-entering legal sources, one of which is the living law in the development of national law.

\section{Research Methodology}

This research is a type of normative legal research. Normative legal research is doctrinal legal research or theoretical legal research. It is called normative legal research because what is examined is the law of the theoretical or normative aspects, not to review the applied aspects of their implementation. The approach used is philosophical. A philosophical approach is an approach that views law as an ideal set of values, which should be a reference in the formation, regulation, and implementation of law. A philosophical approach is used because this study is ideal by using a legal philosophy perspective that views law as law in ideas. The data used is secondary data. Secondary data is data that is not obtained by researchers directly or originating from other parties in the form of written documents. The researcher obtained data through searching library materials online. The data collected will be analyzed qualitatively. A qualitative data analyst is a form of analyst by interpreting and describing data through words in a narrative with scientific logic.

\section{Discussions}

\section{The Development of National Law}

The development of national law is the equivalent of the word development of national law and law. In general, legal development is interpreted as an effort to form a new law to renew old laws that are already irrelevant. Updating means that replacing old laws with new laws. The development of law in this context means the reform of the law. Whereas the national law is a law which is built based on the constitution and Pancasila as the basis of the state (Hamzani, 2012: 3) or law built on the taste and engineering of the Indonesian people.

The development of national law is one of the national development strategies that has aged approximately four decades since the declaration of the legal and development model in 1970 (Halim, 2014: 240). The scope of legal development can be through legislation also through the functionalization of the living law. Legal development is through legislation such as the establishment of legislation or positive law. 
Whereas legal development through legal functionalization that lives in the community can be through obedience to customs and jurisprudence. However, the direction of legal politics in Indonesia in the legal development of its scope simplifies the list of legal (substance) plans that will be made in the National Legislation Program (Prolegnas) (Mahfud, 2007: 3-4). The Indonesian government has long made efforts to establish national law through legislation. The way that has been taken is patchier, namely replacing provisions that are out-to-date, and forming new laws that are partial to certain fields.

These efforts and efforts to have their own laws in accordance with the desired legal products (ius constituendum) continue to be carried out through the National Law Development program. The absence of the national product legal system itself is one of the legal problems in Indonesia that has emerged since the beginning of independence until now. For this reason, the effort to develop the law in Indonesia must be in accordance with the foundation and national objectives to be achieved as stated in the 1945 Constitution of the Republic of Indonesia (UUD NRI), namely: "... protecting the entire Indonesian nation and the whole Indonesian blood and to promote public welfare, educate the life of the nation, and participate in carrying out world order based on freedom, eternal peace, and social justice (Erfandi, 2016: 23-24). The imposition of responsibility for advancing public welfare must have implications for the legal products that are built, without which only new conflicts will arise in the future.

The development of law is directed at the realization of a national legal system that serves the national interests with the initial preparation of legal material that comes from Pancasila and the 1945 Constitution of the Republic of Indonesia, specifically the preparation of new legal products that are needed to support the general tasks of national government and development. As an implementation, national law must serve national interests and achieve people's welfare, justice, and public order (Randang, 2009: 2).

The development of national law is directed towards the realization of a national legal system that serves the national interests whose material comes from the views and beliefs of the Indonesian nation. Likewise, for new issues that must be responded to by the legal need to support the general tasks of government and advance national interests. The long-term direction of development in the development of national law has been proclaimed whose goal is to replace the products of Dutch colonial law with national law through statutory law. 
Post-reform, legal development underwent major reforms as a continuation of demands for reform in various sectors of life including the development sector. Mentioned in Appendix of Act No. 17 of 2007 concerning the National Long Term Development Plan 2005-2025 Chapter II Chapter G that efforts to realize the national legal system continue to include several things including: "...Development of legal substance, both written and legal written as a mechanism to establish national law that is better suited to the development needs and aspirations of the people..."

The fundamental problem in building a national legal system that is no less important is how to make a legal system conducive to the diversity of subsystems, the diversity of substances, and the development of legal fields needed by the community. In addition, the legal system is also conducive to the creation of public legal awareness, legal freedom of the people and the freedom to exercise rights and obligations in accordance with applicable regulations (Randang, 2009: 4).

The State of Indonesia by the founding fathers was idealized as a rule of law. But the blueprint and the design macro description of the idea of the rule of law have not yet had a comprehensive formula other than sectorial and partial legal development. This is not consistent with the civil law legal tradition that tends to prioritize legislation (law making), and adheres to the paradigm and doctrine of fiktie which assume that once a legal norm is established, at that time everyone is considered to know the law. Even though the legal culture in Indonesia is still weak, and legal education is still a homework that has never been resolved properly in the context of the development of a just and impartial national law. Thus, the concept adopted by Indonesia in the development of law is to place laws and products. Others as a means of community development that emphasizes legal functions as; maintainer of security and order, means of development, and public education facilities (Hamzani, 2018: 367) so that the legal objectives are achieved as "community guards."

\section{Sources in the development of national law}

Legal sources, in general, are anything that can give rise to legal rules and where the rule of law is found. In general, the sources related to the law have the equivalent meaning of the word source (English) and brown (Dutch). According to the Indonesian General Dictionary, the source is the origin of something or where something is taken (Poerwadarminta, 1976: 976). The word 
source is connected with the word law to be the source of the law meaning where the origin of law originates. Legal sources differ from a legal basis, legal basis, and legal umbrella. The legal basis is a legal basis or legal ground, namely legal norms that underlie a certain legal action or action so that it can be considered legitimate or can be justified legally (Soeprapto, 1999: 28-30).

Definitely, the source of law is everything in the form of writing, documents, manuscripts, etc. that are used by a nation as a guide in making a decision at a certain time (Sudarsono, 2007: 45). The legal source of its position is very urgent for a country because it is very closely related to the formation of law (law-making) and its implementation (law enforcement).

Experts provide a varied view of the source of the law along with all the impacts caused by these views. According to Paton the source of law is a matter of legal philosophy or legal philosophy, so it has many meanings (Soeroso, 2005: 130). According to Hans Kelsen, the source of law (source of law) contains a lot of understanding. First, what can be understood as two sources of law are custom and statute. Therefore, the source of law is commonly understood as a method of creating law. Custom and legislation are namely customary and statuary creation of law. Second, the source of law can also be linked to ways to judge reason or the reason for the validity of law. Third, the source of law can also be used for things that are non-juridical, such as norms, morals, ethics, political principles, or opinions of experts, and things that can influence the formation of a legal norm, so that it can also be called as a source of law or the source of law (Kelsen, 1973: 209-220).

C.S.T. Kansil said that what is meant by a legal source is anything that creates rules that have a force that is compelling, namely rules which if violated result in strict and real sanctions. The meaning of "everything" is the factors that influence the emergence of law. Whereas the factors that are the source of the force of the formal enactment of the law are where the law can be found, from where the law originates, where the law can be sought or where the judge can find the law as the basis of his decision. However, it should also be noted that sometimes the source of law is also at the same time a law, for example a judge's decision. According to Van Apeldoorn the words of legal sources are used in various ways, and vary depending on the establishment of each questioner, whether by a historian, a philosopher, or a practical legal expert (Kansil, 1982: 34).

According to Theresia Ngutra, the source of law is anything that creates binding and compelling rules, so that if the rule is violated it will cause strict and real sanctions for violators. The source of law in its meaning is that the 
origin of the law is in the form of a decision of the authority authorized to give the decision. That is to say, the decision must be from the competent authority for that (Ngutra, 2016: 195).

The source of law in the sense of legal origin, leads to an investigation of authority, to investigate whether a decision originates from a competent authority or not. The decision of the competent authority can be in the form of a regulation which can also be in the form of a decree. The source of law in its meaning as a place is stated legal regulations. The source of law in this sense carries the law in the investigation of kinds, types, and forms of regulations and provisions. In addition, the legal understanding in the sense as - things that can or should influence the leader in determining the law. For example, is; the belief in the law, a sense of justice, the feeling of the law either from the ruler or the people and also the theories, opinions, and teachings of legal science ((Ngutra, 2016: 194).

Legal sources known in law in their nature are divided into two (2) types, namely sources of material law and formal legal sources.

\section{a. Source of material law}

The source of material law is a source of law that is still in the form of legal materials that do not yet have a certain form and have not been formally binding. According to Paton, the source of material law is the source from which material; material and legal content is drawn (Paton, 1951: 139). Sudikno Mertokusumo (2011) states that the source of material law which is the place from the legal material that is taken. The source of law in the material sense is a belief or feeling of individual law and public opinion that can determine the contents of the law. Beliefs or legal feelings of individuals (as members of society) and public opinion are factors that can influence legal formation (Marwan, 2004: 58).

Factors that can influence the contents of the law can be distinguished into ideal factors and real-community factors. The ideal factor in question is the fixed standards of justice. The form can be in the form of religious views, decency, and tradition. While the real-community factor is a factor that really lives in that is subject to the applicable provisions (Marwan, 2004: 59). The form can be in the form of social relations, relations of political power, socioeconomic situation, and results of scientific research, international developments, and geographical conditions. 


\section{b. Sources of formal law}

The source of formal law is a source of law that is reviewed in terms of its form already has a certain form. Because it already has a certain form, it can be found and recognized by a form of law that is a factor in the enforcement of rules or rules of law. According to Paton, the source of formal law is a source from which the power of attorney is withdrawn or force is binding (Paton, 1951: 140). Formal legal sources in the state administration are known as kenbron.

Named by formal legal sources because of its positive law arises by no longer questioning the origin of the contents of the legal rules. Formal legal sources are used by judges, prosecutors and legal counsel as a basis or consideration for making decisions, formulating demands and or as legal advice to clients. If a rule is contained in a formal legal source, then the rule is basically formal (independent of its contents) and recognized as a binding legal rule (Algra, 1983: 16-17). In general, the sources of formal law consist of; statute, customs, jurisprudence, treaty and doctrine.

\section{1) Statute}

The statute is a statutory regulation formed by the House of Representatives with the President's agreement (Article 1 number 3 of Law No. 12 of 2011) (Wijayanti, 2013: 183). In other words, the Law is a written regulation made by state equipment and is stated in the laws and regulations. Legislation has two main functions, namely as legalization and legislation. Legalization means ratifying phenomena that already exist in society, while legislation is a process for carrying out legal reforms.

The existence of laws and regulations, both as a forum and a process, by adherents of a sociological view is considered a social institution. Viewed from a legal standpoint as a system, legislation is part of a structure which is also one of the formal legal sources.

The statute in Indonesia is determined by the president together with the DPR. Based on the first amendment to the Basic Law of the Republic of Indonesia in 1945 in Article 5 paragraph (1), it was stated that "the President has the right to submit a draft law to the House of Representatives". Then in Article 20 paragraph (1), it is stated that "the House of Representatives holds the power to form laws". Article 20 paragraph (2) that "Every draft law is discussed by the House of Representatives and the President for mutual agreement." To implement legislation that involves the role of the people's representatives, the head of government concerned is also authorized to make implementing regulations. Therefore, the President is also authorized to issue Government 
Regulations and Presidential Regulations. Likewise, Governors, Regents, and Mayors, in addition to jointly representatives of the people form regional regulations, are also authorized to issue regional head regulations as an implementation of these higher regulations.

Indonesian law uses the principle of "lex superiori derogat lex inferiori", which means that higher regulations ignore or override the rules below. According to Republic of Indonesia Law Number 12 of 2011 concerning the Establishment of Legislation, in the formulation of legislation, it must be carried out based on the principles of good legislation, which include: a) Clarity of objectives, b) Institution or appropriate forming officials, c) Conformity between types, hierarchies and content material, d) Can be implemented, e) Usability and success, f) Clarity of formulation, and g) Openness.

The Indonesian state also places Pancasila as the source of all sources of state law. All existing legal regulations must be in accordance with the values contained in the Pancasila. While the type and hierarchy of laws and regulations according to Republic of Indonesia Law Number 12 of 2011 concerning the Establishment of Legislation are as follows: a). 1945 Constitution of the Republic of Indonesia; b). Decree of the People's Consultative Assembly; c). Substituting Government Laws/Regulations; d). Government Regulations; e). Presidential Regulation; f). Provincial Regulations, and g). Regency/City Regulation.

The legislation includes regulations stipulated by the People's Consultative Assembly, the House of Representatives, the Regional Representative Council, the Supreme Court, the Constitutional Court, the Supreme Audit Agency, the Judicial Commission, Bank Indonesia, the same level of established Ministers, Agencies, Institutions or Commissions by Law or Government at the behest of the Law, Provincial Regional Representative Council, Governor, Regency/City Regional Representative Council, Regent/Mayor, Village Head or equivalent. The laws and regulations are recognized and have binding legal force insofar as they are ordered by higher legislation or established based on authority.

\section{2) Custom}

Habits are human actions which are still carried out repeatedly in the same thing. If a certain habit is accepted by the community, it is always repeated, actions that are contrary to the habit are perceived as violations, and then a legal habit arises, which is considered as law by life. 
Utrecht states that customary law is the rules that, although not determined by statutory bodies, in an atmosphere of "werkelijkheid" (reality) are also obeyed, because people are able to accept it as a law, and these rules are maintained by the rulers of society. Habit is a rule of law even though it is not written in the law, and its strength is the same as written law. Especially, the habit gets attention from the government (Utrecht, 1989: 120-122).

According to Sudikno Mertokusumo, habits are actions according to a pattern of behavior that is permanent, steady, prevalent, normal or customary in society or certain social relationships. Fixed or steady behavior is repeated human behavior, where repeated behavior has normative strength and has binding strength. Because it is repeated by many people, it binds other people to do the same thing and raises confidence or awareness that it is indeed worth doing (Mertokusumo, 2011: 110).

Behavior size is custom or custom is propriety, not merely the element of repetition or the attitude of behavior. Because this is felt to be appropriate, then it is repeated, and it is appropriate whether or not this behavior is not because of someone's opinion but the opinion of the community. Not all habits or customs must be a source of law. It is only the habits and customs that are good and accepted by the community that is in accordance with the personality of the community that develops into customary law. Conversely there are habits that are not good and rejected by society, and this will not be a customary law of the community. For example; the habit of staying up late, dressing up in clothes, speeding, and so on.

Habits in Indonesia are regulated in several laws, namely, among others: Article 1339 of the Civil Code that; "The agreement is not only binding on matters that are expressly stated in it, but also for everything that according to the nature of the agreement is required by propriety, custom or law." Furthermore, in Article 1571 of the Civil Code it is also stated that: "If the lease agreement is not made in writing, then the lease agreement does not expire at the specified time, but if the one party notifies the other party that he wants to terminate the agreement which is according to local customs (Soeroso, 2005: 155)."

\section{3) Jurisprudence}

Jurisprudence is the decision of the previous judge on a case that is not regulated by law and made a guideline by another judge in deciding the same case (Nurhardianto, 2015: 42). Jurisprudence is born because of the existence of 
laws and regulations that are lacking or unclear, or there are legal cases but there are no laws and regulations that govern them, making it difficult for judges to decide on a case.

Some reasons for a judge to use another judge's decision (jurisprudence) to deal with the same case are: First, psychological considerations. This is especially true of decisions by the High Court and the Supreme Court, so in the case of the same cases, the judge below him will psychologically follow the judge's decision on it. The second is the practical considerations. This is usually the case in a case that has been handed down by a previous judge, especially when it has been strengthened or justified by the High Court or the Supreme Court. The judge considers it more practical to give the same decision. In addition, if the decision of a lower level judge gives a deviant decision or differs from a higher decision for the same case, usually the decision is defeated at the time of appeal or cassation. The third is the same opinion. The same opinion occurs because the judge in question agrees with the decision of another judge beforehand for a similar or similar case.

\section{4) Treaty}

The treaty is an agreement made by two or more countries. The result of this agreement is that the parties concerned are bound by the agreement they have held. Also referred to as Pacta Sun Servada, which means the agreement binding on the parties that make or each agreement must be adhered to and kept by both parties (Soeroso, 2015: 157).

There are 3 (three) types of treaties, namely: bilateral treaties, multilateral treaties, and collective treaties. Bilateral treaties are also called binational treaties (twee zijdig), namely an agreement carried out by two countries. Example: Treaty between the Indonesian government and the Malaysian Government regarding the extradition treaty concerning ordinary criminal crimes and political crimes. The multilateral treaty is an agreement made by many countries. Example: Agreement on cooperation between several countries in the field of defense and ideology such as NATO. Collective treaties, also called open treaties, are agreements made by several countries or multilateral which are then open to other countries bound to the agreement. Example: An agreement in the United Nations where other countries are open to participating in becoming a member of the United Nations which is bound by the agreement established by the UN. 
5) The opinion of lawyers (doctrine)

According to Sudikno Mertokusumo, the opinion of legal scholars who are doctrines is a source of law. Law is a source of law but not law because it does not directly have binding powers as a law. The opinion of a legal scholar (doctrine) is the opinion of someone or some legal scholars who are well-known in legal science. Doctrine is the opinion of leading legal scholars and its influence on judges in making decisions (Mertokusumo, 2011: 110).

Doctrine can be the basis for judges' consideration in making their decisions. For example, a judge in examining a case or in consideration of his decision can mention the doctrine of a particular legal expert. The judge is deemed to have found the law through a source of law in the form of the doctrine. The judge in deciding the case is usually based on laws, international agreements and jurisprudence. If the three sources cannot give all the answers to the law, then the law is sought in the opinion of the law or law scholars.

\section{The importance of the Living Law as a Source in the Development of National Law}

Legal development is a conscious, systematic and continuous effort to build the life of a society, nation, and state that is more advanced, prosperous, safe and peaceful in the frame and a fair and definite legal basis (Setiadi, 2012: 5-6). So, if the direction of the development of the national legal system starts from lawmaking, it must be able to replace all kinds of laws on Dutch Colonial products such as the Criminal Code, Civil Code, Commercial Law, perfecting and changing legislation -the product itself is no longer in line with the times.

The material is based on the views and beliefs of the Indonesian people, in addition to considering global developments. The development of national law must also respect unwritten law such as customary law and Islamic law which has long been the living law. In the context of Islamic law, its existence has become an inseparable part of Indonesian society, not only at the symbol level but also at the practical level and its existence has been recognized as the raw material for national law, in addition to customary law and general law. Even Islamic law has a more strategic position because of its character which emphasizes religious morality in the form of accountability before God (Sirajuddin, 2009: 808).

In terms of implementing Islamic law, there are various things. Some can be carried out by individuals without state or community assistance such as the 
laws in the area of ritual worship. There are those whose implementation requires assistance from state power in an administrative or service framework such as family law. Some are not possible without state intervention, such as criminal law (Anwar, 2010: 16).

The transformation of parts of Islamic law into national law in principle is a continuation of what has been going on for a long time. Its applicability is not something new, and not utopian, but has a long historical root. Islamic law in Indonesia is a law that lives, develops, is known and partly obeyed by Muslims. Since the colonial rule of the Netherlands until post-independence, Islamic law in force in Indonesia is indeed limited to the law of practical worship, family law (ahwal al-syakhsiyah) only. Later, it expanded into engagement law (muamalah) such as the sharia economy, sharia banking, and sharia insurance. The criminal law is actually debatable because since the colonial period the Dutch government was kept away from Muslims.

Islamic law in the public sphere in the Indonesian context has been guaranteed and regulated in the 1945 Constitution of the Republic of Indonesia Article 29 paragraph (1): "Every citizen is given the freedom to embrace religion and belief and practice their respective religions and beliefs". According to Hazairin, there are six meanings related to this article, three of which involve the application of religious laws including Islamic law.

First, in the Republic of Indonesia, there must not be a rule that is contrary to the rules of Islamic law. Second, that the Republic of Indonesia is obliged to implement Sharia-Sharia-Religion: Islamic Sharia for Muslims, Christian Sharia for Christians and Hindu Sharia for Hindus, as long as the implementation of Sharia requires the help of state power. The third is that the Sharia which does not need the help of state power to implement it, because it can be carried out by each of the followers of the religion itself, becomes a personal obligation for each person who runs himself according to his own religion (Hazairin, 2007: 14-15).

For this reason, when looking at Islam (religion) law in the context of the development of national law, it must at least look at four things:

a. The obligation for Muslims to carry out/apply all the teachings of Islam, including its legal aspects if you want to be a devout religion.

b. The condition of a diverse Indonesian nation with a plurality of religions, cultures and espoused values. 
c. There is a dichotomy in studies in Indonesia, namely Western law in the faculty of law, Islamic law in the Shariah faculty, so that when someone starts studying law at the law faculty, what is learned and developed is Western legal theory.

d. The absence of the same conceptions and strategies within Muslims is related to the position of Islamic criminal law, whether as a formal source or sufficient as a source of material/material.

Many studies have been carried out in the form of seminars, workshops, and research in order to replace the Western laws of the Dutch colonial heritage which are often justified not in accordance with national culture. Not a few scientific works have tried to explore the wealth of Islamic legal theories to be juxtaposed and made a comparison with Western legal theory. The law that provides theories is Western law and Islamic law. The relationship between customary law and Islamic law actually does not need to be disputed, because, in Islamic law, adat ('urf) can be used as a source of law (al-adat muhakkamah). It remains that Islamic law and Western law need to be studied further. The theoretical competition for the formation of national law depends on the extent to which the two legal systems can provide a theoretical foundation in a broad sense that is in accordance with the Indonesian context.

From these findings, it seems that implementing an accommodative policy on a variety of heterogeneous sources including Islamic (religious) law is a very necessary thing. This policy should have been done so that the national law produced is truly a legal product capable of protecting and protecting all heterogeneous components of the Indonesian nation with their respective backgrounds and legal needs, including Muslims. Because of the consequences of tangible diversity, one of the impacts is the rise of ways or points of view in living law (religious law), especially on Islamic religions (Itmam, 2013: 278), and the necessity of living law to be accommodated and transformed in the rules of national law.

The application of accommodative policies to legal sources, including the religious law in the perspective of the insight into the development of national law is actually a manifestation of the insights of Bhineka Tunggal Ika. Ismail Saleh argues that even though unification is the goal of the formation of national law, for the sake of national legal justice that will be realized, it must pay attention to differences in socio-cultural background and differences in legal needs of certain groups so that the community group gets the fairest treatment. With Bhinneka Tunggal Ika annihilation alongside the Archipelago's Insight and Nationalism, then the unification of the law sought will at the same 
time guarantee the accommodation of aspirations, values and legal needs from various groups of people into the national legal system. In other words, the development of national law must still provide a separate space for "community laws" to be able to coexist with other modern national legal systems (Adhayanto, 2014: 29).

As stated by Ahmad Gunaryo, there must be legal reconciliation that is accommodative of the dynamics of Islamic law so that through a reconciliation of Islamic law with national law a real national law will be formed (Itmam, 2013: 279). This is in accordance with the mandate of the State Policy Guidelines (GBHN) that legal development policies must be accommodative and responsive to the reality of the plurality of values (laws) that live in society. It was also stated in the MPR Decree No. IV/MPR/1999 that the problem of national development in the field of law, especially the legal aspects of the material, is directed at the realization of a national legal system that serves national interests through the preparation of comprehensive legal material sourced from Pancasila and the 1945 Constitution by observing the prevailing legal diversity. Therefore it is necessary to continue the preparation and process of implementing the national legislation program in an integrated manner, which includes replacing the legacy of colonial legislation with legislation originating from Pancasila and the 1945 Constitution, replacing national legislation that still contradicts both horizontally and vertically with each other, and the establishment of legislation that is able to answer the demands of the times.

Referring to this policy, the context of the development of national law in its preparation must be open from various sources of law whether in the form of customary law, religious law, and western law of inheritance which is still considered relevant, as well as laws from outside countries. All sources of legal material must first have been studied in depth so that universal values and principles can be found so that there are no fundamental differences between the sources of the legal material, and do not conflict with the values contained in the Pancasila and the 1945 Constitution of the Republic of Indonesia. These universal values and principles of law were developed and adopted as concrete normative legal principles in the future national law.

Particularly, it is related to the values of religious law as a source for efforts to develop national law. W. Friedman (1983) argues that "the need for religious instruction is because religion can measure the true value of religion. It is the principles of religion that make justice from a practical form and it is only owned by religion." The importance of using the basis of religious law 
values is relevant to be put forward because the national law to be formed later must be rooted while manifesting the sense/value of justice that exists in people's lives. Whereas, one of the sources of views which on the value of justice of the community is religious teachings that are united with the beliefs of their followers.

The development of national law that is responsive to the values of the teachings of religious law is in accordance with the demands of justice. Even in the perspective of international trends, attention to religious values is also increasingly becoming the awareness of a large number of countries, especially those whose national legal system has still inherited from foreign law inherited from the invaders. Therefore, it has become imperative that forming national laws must reflect the moral norms of society which are appointed as legal norms that bind all citizens in the life of society and the state. National lawmaking must also understand the values and beliefs held by the community to which the law will be enforced (Arifin, 2001: 36).

If you probe into the Pancasila as an ideology and the foundation of the state, which stems from the belief that the natural world with everything in it as a whole that is interwoven harmoniously created by God Almighty (YME), also humans are created by God Almighty. Humans come from God and the ultimate goal of life is to return to their original source, therefore fearing and serving God is a proper and proper human obligation. Then the Indonesian national legal system should not close the opportunity for efforts to implement the entry of religious law or the rules of religious law into the national legal system. Because, it is basically, historically, sociologically and philosophically, the Indonesian legal system is based on Islamic law, in addition to western (Dutch) law and customary law (Yunus, 2015: 264).

Thus, the national legal system is a legal system that is not based on a particular religion but gives a place to the religions adopted by the people to become a source of law on national legal products. Religious law as a source of law here is interpreted as a source of material law (source of legal material), except for certain legal fields that apply only to certain religious communities can also be a source of formal law. For example; for Muslims, the law is regarding zakat, waqf, organizing a hajj which only applies to Muslims, or certain rules in marriage which according to each religion are different. These legal arrangements are only administrative in nature.

The values that are believed and developed in the community should be used as a source in the development of national law. Laws derived from religious teachings are part of the values that develop in society. Measures to 
criminalize an act, its resolution and sanctions, of course, must also pay attention to the collective values and views in the community about what is right, good, useful or otherwise. The law produced in the future is in accordance with legal awareness and willingness of the people. So that a culture of constitutional society is formed, not only to implement the laws and policies and policies made, but to be able to contract with the implementation of laws, policies, and even state administrators (Usman, 2014: 27).

The aspiration to build national law is also a dialectical struggle between the tendency to escape from the colonial legal system and the tendency to feel comfortable with the legal system (status quo). It has become a historical record of the nation's struggle through the Jakarta Charter consensus to the compromise efforts of pre and posts the proclamation of Indonesian independence on August 17, 1945 with the present Pancasila formula. This shows that Islamic (religious) law already has historical and sociological roots, and has a long history of struggle for existence. This can be proven that since the Islamic religion was embraced by the population, Islamic law began to take effect in the governance of social life. Legal norms or rules serve as guidelines for life after first experiencing acculturation (Nawawie, 2013: 2).

According to the author, to be able to contribute to the development of national law, the position of religious law, especially Islam should be a formal legal source for the civil sector and applies exclusively to Muslims. Because, Islamic law in Indonesia in the field of private (especially) family law (ahwal alsyakhsiyah) is a law that lives, develops, is known and adhered to by Muslims. The state must also respect the plurality of laws for its pluralistic people, in line with the principles of Unity in Diversity. Such as Islamic marriage law and inheritance law should be recognized and apply both to the laws governing materially, as well as by being appointed by law as in the field of marriage. Republic of Indonesia Law Number 1 the Year 1974 concerning Marriage explicitly states that marriage is legal when carried out according to their respective religious law and belief. That is, the validity of marriage for a Muslim/Muslim woman is legal according to Islamic law. Just as in the VOC era there was a Compendium Frijer, then in the New Order period a Compilation of Islamic Law was also formulated, although the basis for its implementation was only based on the Presidential Instruction.

Islamic law in the field of worship practically applies without having to lift it into positive law, as formalized in the form of legislation. If arrangements are needed, only rules that can provide flexibility to Muslims to carry out the laws of worship, or at the most far are aspects of state administrative law to 
facilitate the implementation of a rule of Islamic law. How does Islamic law regulate the procedure of carrying out five daily prayers, fasting and the like do not require positive law? Likewise, the field of Hajj and Zakat if there is a law that regulates it only limited to the administration and administration relating to the functions of the state which must provide services to its people. Other examples in the field of employment law and labor are limited to providing opportunities for Muslim employees and workers to perform Friday prayer, whereas relating to criminal law should be a material source of material (material) only. Because criminal law is the public sphere whose enactment adheres to unification or a law that applies nationally to all Indonesian people, whatever their religion. As a public law that applies by unification, national criminal law is not based on a particular religion but gives a place to the religions held by the people to be a source of material law or legal material. Not only Islamic law is used as a source of material law, but also customary law, including the laws of Dutch colonial inheritance if it is still considered in line and accepted by society, and various international conventions.

If you want to examine, in any country, unless the country is truly secular, in formulating the rules of national law it is always influenced by religious law. The Indian constitution expressly states that India is a secular state, but who can deny Hindu law has influenced modern Indian law. Buddhism is also very influential on the national laws of Thailand and Myanmar. The Philippine Marriage Law which prohibits divorce is also strongly influenced by Catholic teachings. Thus, it can be affirmed that religious law, especially Islam is a law that lives in Indonesian society. Development of national law must not ignore religious law, including Islam. Moreover, formulating provisions that conflict with religious law, such as Islamic law, will certainly get resistance from Muslims. The state must build laws in accordance with the legal awareness of its people.

According to Mahfud MD in the National Long Term Development Plan for 2005-2025 the development of the law was directed at the realization of a national legal system that was firmly rooted in Pancasila and the 1945 Constitution. Legal development must be able to produce legal product reforms to replace the colonial legacy regulations that social values and interests of the Indonesian people as well as being able to encourage the growth of the administration of national government and development that originated from Pancasila and the 1945 Constitution while taking into account the plurality of applicable legal orders and the influence of globalization (Mahfud, 2009: 296297). The problem of Indonesian law which is from the past until now is the root of the Indonesian legal system which lies in the legal system of its former 
colonizers, the Netherlands. Consequently, Indonesian law is pluralistic and there is a prolonged conflict with people who want to include customary law and Islamic law as living laws in Indonesia (Bedner, 2013: 255).

The conflict between colonial law, customary law, and Islamic law naturally give birth to dishonor for the development of national law. The best solution that can be done is to reconcile by developing national law must be able to accommodate and incorporate the values contained in the three laws, there must be no one superior or inferior among them, and at the same time must see the legal culture of culture in certain communities where religious law is implemented and becomes the lifeblood of their lives. Incorporating religious law in the national legal system, both formal and material, is a step forward in legal development, while at the same time looking at the slaughtering of the interests of the greater community.

\section{Conclusion}

From the above studies, it can be understood that the development of national law should pay attention to existing legal sources, especially laws that have become community culture. Incorporating religious law into the development of national law basically facilitates legal work in applications in the community, because people are used to it, and it will not be difficult in the implementation process. In the Indonesian context, there is still a diatomic between religious law, customary law, and colonial inheritance law. This dichotomy then made the process of distinctive and Indonesian legal transformation still far from the fire. Moreover, there are still a handful of people who feel that the laws of colonial heritage are very sacred and cannot be manipulated.

Departing from this, then considering the living law as a source in the development of national law is a necessity that cannot be denied. Moreover, the mandate of the National Long-Term Development Plan for 2005-2025 where legal development must be able to produce legal product reforms to replace colonial legacy legislation that reflects the social values and interests of the Indonesian people and is able to encourage the growth of national governance and development on Pancasila and the 1945 Constitution. If you want to look a little at other countries, except for a secular state, you will find an understanding that everything in formulating the rules of national law is always influenced by religious law. 


\section{References}

\section{Buku}

Algra, N.E. dkk., Mula Hukum, Jakarta: Bina Cipta, 1983.

Anwar, S. Hukum Perjanjian Syariah, Jakarta: PT. Raja Grafindo Persada, 2010.

Arifin, B. Pelembagaan Hukum Islam di Indonesia, Jakarta: Gema Insani Press, 2001.

Hazairin. Etika Hakim dalam Penyelenggaraan Peradilan; Suatu Kajian dalam Sistem Peradilan Islam, Jakarta: Kencana Prenada Group, 2007.

Kelsen, H. General Theory of Law and State, New York: Russel, 1973.

Marwan, M. Pengantar Ilmu Hukum, Jakarta: Galia Indonesia, 2004.

Mertokusumo, S. Sejarah Peradilan dan Perundang-undangannya di Indonesia Sejak 1942 dan Apakah Kemanfaatannya bagi Kita Bangsa Indonesia, Yogyakarta: Universitas Atma Jaya Press, 2011.

Milovanovic, D. A Primer in the Sociology of Law, Second Edition, New York: Harrow and Heston, 1994.

Paton, G.W. A Textbook of Jurisprudence, Oxford: Clarendon Press, 1951.

Poerwadarminta. Kamus Umum Bahasa Indonesia, Jakarta: Balai Pustaka, 1976.

Rahardjo, S. Ilmu Hukum, Bandung: Aditya Bakti, 2012.

Rahardjo, S. Membedah Hukum Progresif, Jakarta: Kompas, 2008.

Soeprapto, M.F.I. Ilmu Perundang-undangan, Dasar-dasar dan Pembentukannya. Yogyakarta: Kanisius, 1999.

Soeroso. R. Pengantar Ilmu Hukum, Jakarta: Sinar Grafika, 2005.

Utrecht, E. Pengantar dalam Hukum Indonesia, Jakarta: Sinar Harapan, 1989.

\section{Artikel/Prosiding}

Abel, R. "What Else is Sociology of Law? Reflection on John Griffiths's What is Sociology of Law?", The Journal Of Legal Pluralism And Unofficial Law, Vol. 49, No. 3, (2017). DOI. https://doi.org/10.1080/07329113.2017.1375250

Adhayanto, O. "Perkembangan Sistem Hukum Nasional", Jurnal Ilmu Hukum, Vol. 4, No. 2, Februari-Juli (2014).

Bedner, A. "Indonesian Legal Scholarship and Jurisprudence as an Obstacle for Transplanting Legal Institutions", Hague Journal on the Rule of Law, Volume 5, Issue 02, September (2013). DOI: 10.1017/S1876404512001145

Halim, A. "Analisis Kebijakan Pembangunan Hukum Nasional Berdasarkan UU No. 25 Tahun 2004 Tentang Sistem Perencanaan Pembangunan Nasional", Jurnal Al-Mazahib, Vol. 2, No. 2, Desember 2014.

Hamzani, A.I. "Menggagas Pembangunan Hukum Nasional Berbasis Relegius; Studi Terhadap Peluang Kontributif Hukum Islam Dalam Arah Pembangunan Hukum Nasional", Jurnal Hukum Islam (JHI), Vol. 10, No. 1, Juni 2012. 
Hamzani, A.I.M; \& Rahayu, D.P. "Pembangunan Hukum Nasional Sebagai Implementasi Tujuan Nasional, Prosiding SENDI-U, 2018.

Itmam, M.S. "Hukum Islam dalam Pergumulan Politik Hukum Nasional Era Reformasi", Jurnal Al-Tahrir, Vol. 13, No. 2 November (2013). DOI. https://doi.org/10.21154/al-tahrir.v13i2.17

Kabalmay, H.A. "Keadilan Sebagai Tujuan Hukum; Suatu Kajian Filsafat", Tahkim, Vol. VI No. 1, Februari (2010).

Kansil, C.S.T. Introduction to Indonesian Law and Law, Jakarta: Balai Pustaka, 1982.

Mahfud, M.D. "Capaian dan Proyeksi Kondisi Hukum Indonesia", Jurnal Hukum, No. 3, Vol. 16, Juli (2009). DOI: https://doi.org/10.20885/iustum.vol16.iss3.art1

Nawawie, H. "Hukum Islam Dalam Perspektif Sosial-Budaya di Era Reformasi", Jurnal Espistime, Vol. 8, No. 1, Juni (2013).

Ngutra, T. "Hukum dan Sumber-Sumber Hukum", Jurnal Supremasi, Volume XI Nomor 2, Oktober (2016).

Nurhardianto, F. "Sistem Hukum dan Posisi Hukum Indonesia", Jurnal TAPIs, Vol.11 No.1 Januari-Juni (2015).

Randang, F.B. "Membangun Hukum Nasional yang Demokratis dan Cerdas Hukum", Jurnal Servanda; Jurnal Ilmiah Hukum, Vol. III, No. 1, Edisi Januari 2009.

Sagama, S. "Analisis Konsep Keadilan, Kepastian Hukum Dan Kemanfaatan Dalam Pengelolaan Lingkungan", Jurnal Mazahib, Vol. XV, No. 1 Juni (2016). DOI: http://dx.doi.org/10.21093/mj.v15i1.590

Setiadi, Wicipto. "Pembangunan Hukum dalam Rangka Peningkatan Supremasi Hukum", Jurnal Rechtsvinding, Vol. 1, No. 1, April 2012.

Sirajuddin, M. "Wacana Penerapan Hukum Islam dalam Tinjauan Politik Hukum Nasional", Sosio-Relegia, Vol. 8, No. 3, Mei (2009).

Usman, A.H. "Kesadaran Hukum Masyarakat dan Pemerintah Sebagai Faktor Tegaknya Negara Hukum di Indonesia", Jurnal Wawasan Hukum, Vol. 30 No. 1 Februari (2014).

Wijayanti, W. "Eksistensi Undang-Undang Sebagai Produk Hukum dalam Pemenuhan Keadilan Bagi Rakyat (Analisis Putusan Mahkamah Konstitusi Nomor 50/PUU-X/2012)", Jurnal Konstitusi, Volume 10, Nomor 1, Maret (2013).

Yunus, N.R. "Penerapan Syariat Islam Terhadap Peraturan Daerah dalam Sistem Hukum Nasional Indonesia“, Hunafa; Jurnal Studia Islamika, Vol. 12, No. 2, Desember (2015). DOI: https://doi.org/10.24239/jsi.v12i2.394.253-279.

Yusuf, A.W. "Hukum dan Keadilan", Padjadjaran Jurnal Ilmu Hukum, Volume 2 Nomor 1 Tahun (2015). DOI: https://doi.org/10.22304 
in Collaboration with :

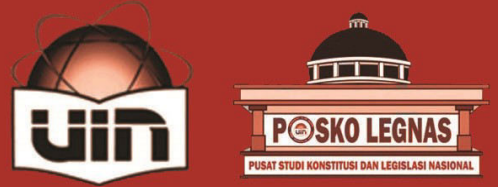

Indexed by :
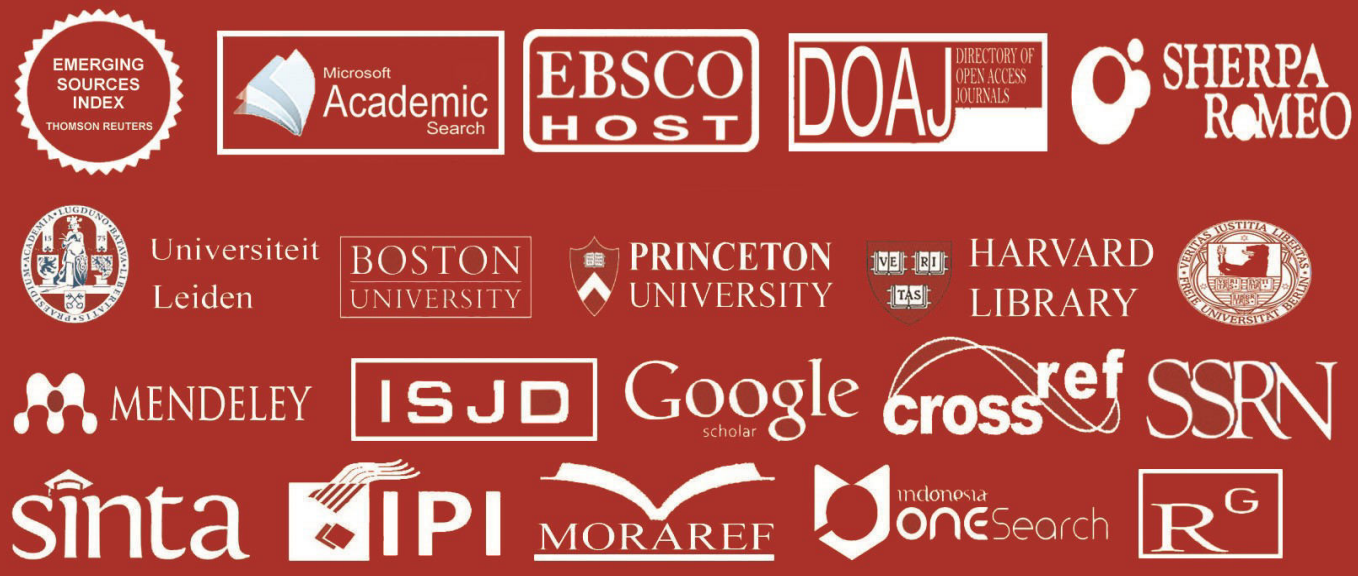

JURNAL CITA HUKUM is a peer-reviewed journal on Indonesian Law Studies published biannual (June \& December) by Faculty of Sharia and Law Universitas Islam Negeri Syarif Hidayatullah Jakarta in cooperation with Center for the Study of Constitution and National Legislation (POSKO-LEGNAS). JURNAL CITA HUKUM aims primarily to facilitate scholarly and professional discussions over current developments on legal issues in Indonesia as well as to publish innovative legal researches concerning Indonesian laws.
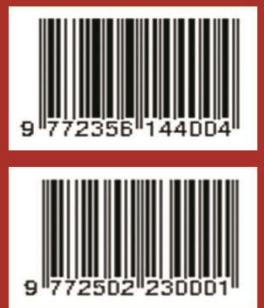